\title{
TL, OSL and C-14 Dating Results of the Sediments and Bricks from Mummified Nuns' Grave
}

\author{
DIEGO R.G. TUDELA ${ }^{1}$, SONIA H. TATUMI ${ }^{1}$, MÁRCIO YEE ${ }^{1}$, SILVIO L.M. BRITO ${ }^{1}$, JOSÉ L. MORAIS ${ }^{2}$, \\ DAISY DE MORAIS ${ }^{2}$, SILVIA C. PIEDADE ${ }^{2}$, CASIMIRO S.P. MUNITA ${ }^{3}$ and ROBERTO HAZENFRATZ ${ }^{3}$ \\ ${ }^{1}$ Faculdade de Tecnologia de São Paulo, CEETEPS/UNESP, Praça Cel. Fernando Prestes, 30, 01124-060 São Paulo, SP, Brasil \\ ${ }^{2}$ Museu de Arqueologia e Etnologia, Universidade de São Paulo, Av. Prof. Almeida Prado, 1466, \\ Cidade Universitária, 05508-900 São Paulo, SP, Brasil \\ ${ }^{3}$ Instituto de Pesquisas Energéticas e Nucleares, Comissão Nacional de Energia Nuclear, \\ Caixa Postal 11049, 05422-970 São Paulo, SP, Brasil
}

Manuscript received on April 15, 2011; accepted for publication on December 13, 2011

\begin{abstract}
This paper presents the results of TL and OSL dating of soil and fragments of bricks from a grave, which was occupied by two mummified nuns, found at "Luz" Monastery, located in the state of São Paulo, Brazil. The TL and OSL ages were compared to C-14 dating ones obtained from bone collagens of the mummies. The majority of the ages is related to the eighteenth century. The gamma-ray spectroscopy was used to evaluate natural radioisotope concentrations in the samples, and by using these concentrations the annual dose rates, from 3.0 to $5.3 \mathrm{~Gy} / \mathrm{kyr}$, were obtained. Neutron activation analysis was performed and the radioisotope contents results are in agreement with those obtained by gamma-ray spectroscopy. The contents of $\mathrm{U}$, Th and Ce elements were higher than those found in usual sediments.
\end{abstract}

Key words: dating, Thermoluminescence (TL), Optical stimulated Luminescence (OSL), Mummified Nuns, Mosteiro da "Luz".

\section{INTRODUCTION}

The thermoluminescence emission of crystals was firstly used for dating geological materials and proposed by Daniels et al. (1953). However, they did not obtain reliable results because the samples used were much older and contained several impurities, which affected the TL emission; at that time, the theory of the impurity role was in full development (Medlin 1959, 1964). Kennedy and Knopff (1960) achieved positive results using young samples,

Correspondence to: Sonia Hatsue Tatumi

E-mail: tatumi@fatecsp.br such as archaeological pottery and volcanic ashes. The work was presented in the "Meeting of the American Association for the Advance of Science". Subsequently, Grogler et al. (1960) published the first scientific paper on TL dating of archaeological pottery. In addition, potteries, funerary urns and tiles were dated continually with success establishing the methodology that is accepted without restriction (Mazess and Zimmerman 1966, Ralph and Han 1966, Mejdahl 1969).

In Brazil, the TL dating research was introduced by Szmuk and Watanabe (1971). They analyzed 
pottery fragments and funerary urns found in the state of São Paulo. Later, Miyamoto and Watanabe (1975) dated archaeological sites from different places, as Lauri Hacienda in Peru, Xingu National Park and Paranapanema Valley. TL dating of pottery fragments is now in widespread use in archaeology (Tatumi et al. 1998, Martins et al. 1999).

The pioneer work in OSL dating was reported by Gozzi et al. (2001). They used quartz in order to obtain the deposition ages of sediments, and the samples were collected from an archaeological site, located in the state of Mato Grosso do Sul, Brazil.

Although there is a large number of works in luminesce dating in the archaeology field, the dating of historical artifacts is scarce even in international studies. Tiles, bricks and mortars are often used in accident dosimetry investigation (Banerjee et al. 1999). Such samples are taken from places where there is some kind of radioactive leak and whose accumulated dose values can be evaluated. Nevertheless, few works about luminescence dating of historical artifacts could be found in the literature as Göksu et al. 2001. They used TL dating of quartz extracted from bricks of a monastery church of Tegernsee, Germany. The ages were obtained by using 210 and $325^{\circ} \mathrm{C}$ TL peaks (Spooner et al. 1990, Mejdahl and Bøtter-Jensen 1994, 1997, Öke and Yurdatapan 2000).

In the present work, TL and OSL datings were used to investigate a grave with two mummified nuns. The grave was found inside the "Luz" Monastery, located at the state of São Paulo, Brazil. The monastery was founded and built by the priest Antonio de Sant'Ana Galvão in 1774 A.D., and in 1943 the Institute for National Artistic and Historical Heritage was in charge of it. It is a very old building that was turned into a museum open to the public, and the mummies of the nuns were found in one of its rooms during a termite control, which infested the building in 2008. The Concepcionistas sisters, even nowadays, are dedicated to prayer and work, living away from the society. The grave had no identification and was in a hollow wall of the museum. In order to obtain the age of the grave, TL and OSL dating methods were used and the results compared to $\mathrm{C}-14$ dating ages.

\section{MATERIALS AND METHODS}

The two mummified nuns are shown in Fig. 1. Three samples of the sediments that covered the nuns, two mud wall samples and one fragment of brick used in the wall of the tomb were collected avoiding the light. The samples, names and features are described in Table I. For conventional radiocarbon dating, two portions of bones samples were extracted from each mummified nun and sent to Beta Analytic Inc, USA.

Pure quartz grains, with their size ranging from 0.075 to $0.150 \mathrm{~mm}$, were obtained after chemical treatment with $\mathrm{H}_{2} \mathrm{O}_{2}$ to eliminate organic materials, HF to eliminate carbonates, feldspars and to remove a small surface layer of the grain, avoiding the alpha ionization contribution, and $\mathrm{HCl}$ to remove fluorides created by HF etching and SPT (Sodium Politungstate) to separate the quartz grains from the heavy minerals.

The TL measurements were obtained through a TL/OSL automated system, model 1100-series of Daybreak Nuclear Instruments Inc. TL measurements were carried out with a heating rate of $10^{\circ} \mathrm{C} / \mathrm{s}$ and using two optical filters (Kopp and BG-39) under nitrogen atmosphere. OSL experiments were performed by stimulation with blue light and the use of an optical filter (U-340).

Gamma irradiation was made at room temperature using a Panoramic $60 \mathrm{C}^{\circ}$ source with a dose rate of $37.7 \mathrm{~Gy} / \mathrm{h}$ at $30 \mathrm{~cm}$ of the source. Radioisotope elements were determined by gamma-spectroscopy with a $\mathrm{NaI}(\mathrm{Tl})$ detector of Canberra and standard soil samples (JR-1, JG-1a, JB-3 and JG-3). Neutron activation analysis was applied to the samples. The samples were prepared by manually grinding, in an agate mortar and pestle, in order to pass through a 100-200 $\mu \mathrm{m}$ mesh 

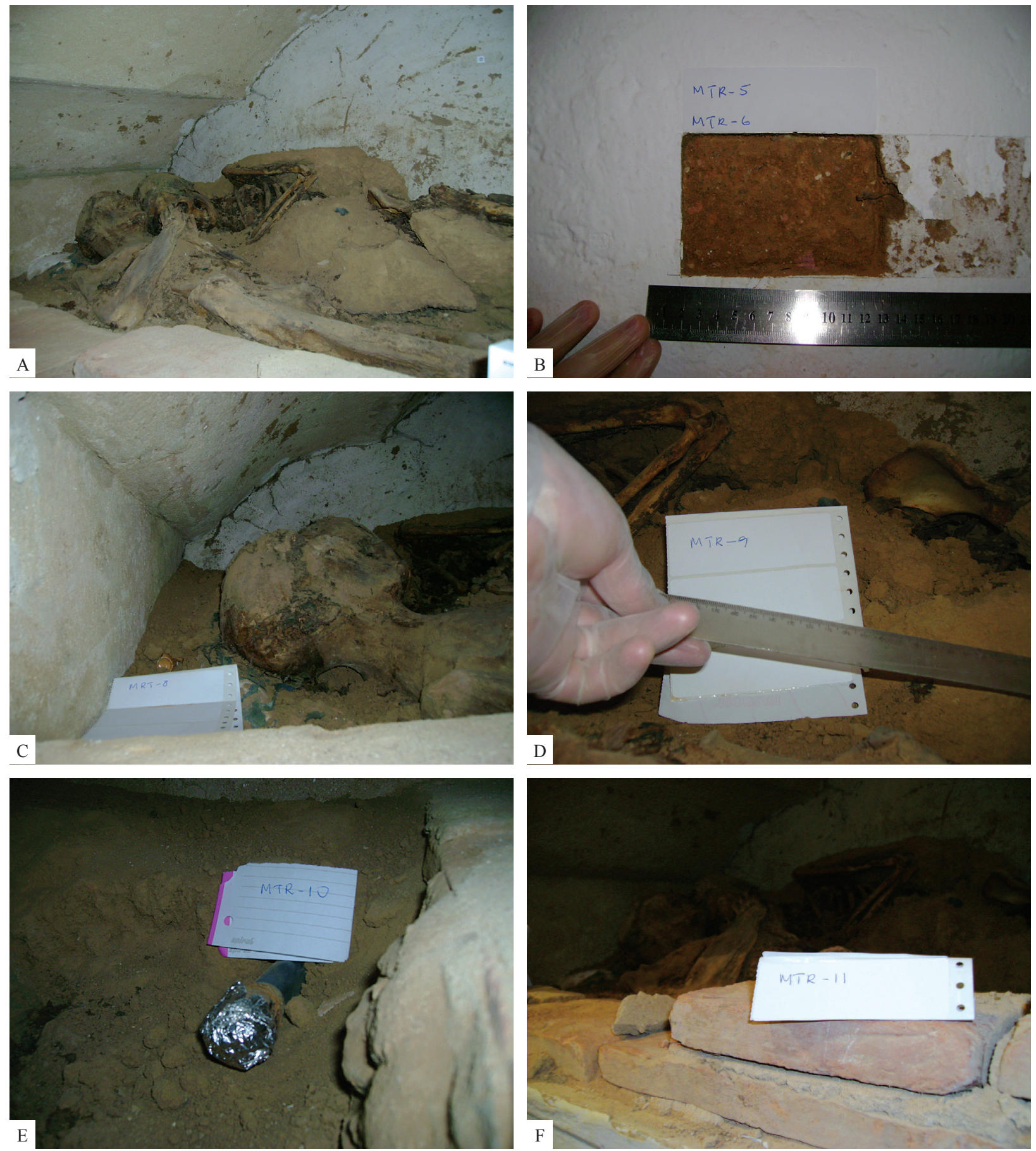

Fig.1: Pictures of the sampling site, a) the two mummified nuns, which were found in the same grave; b) ancient mud wall called "Taipa"; c) sediment collected near the mummy located in front; d) sediment collected between the mummies e) sediment collected near mummy's foot located in bottom fund and $\mathbf{f}$ ) brick of the wall. 
TABLE I

Sample name and descriptions

\begin{tabular}{cl}
\hline Sample Name & Samples features \\
\hline MTR6 & mud wall “Taipa” \\
\hline MTR8 & Sediment collected near the mummy located in front. \\
\hline MTR9 & Sediment collected between the mummies \\
\hline MTR10 & Sediment collected near mummy's foot located in bottom fund \\
\hline MTR11 & Brick of the wall \\
\hline MTR13 & Mud wall of oratory \\
\hline
\end{tabular}

sieve. After this treatment the material became more homogenous, so that it could be used in trace-element analysis. Contamination from agate mortar is not a serious problem, since silicon was not determined. Constituent elements in coal fly ash, NIST-SRM-1633b, were used as a standard, and IAEA - Soil 7 trace elements in Soil were used as check samples in all the analyses. The samples and the standard were dried in an oven at $100^{\circ} \mathrm{C}$ for $24 \mathrm{~h}$ and stored in desiccators until weighing. About $100 \mathrm{mg}$ of the samples and the standards were weighed into polyethylene bags and covered with an aluminum foil. Groups of samples and the reference material were packed in an aluminum foil and irradiated in the swimming pool research reactor, IEA-R1m, from the IPEN-CNEN/SP, at a thermal neutron flux of about $5 \times 10^{12} \mathrm{ncm}^{-2} \mathrm{~s}^{-1}$ for $8 \mathrm{~h}$. The spectra of $\gamma$-rays were obtained after 7 and 25 days of decay time using a Ge-hyperpure detector, model GX 2020, Canberra, FWHM 1.9 keV gamma peak of ${ }^{60} \mathrm{Co}$ and 8192 channel S-100 Canberra MCA.

A protocol of Multiple aliquots additive doses was used for equivalent dose (Q) value determination ( Mejdahl and Bøtter-Jensen 1994). The advantage of this protocol is that there is no change in TL or OSL response per unit of dose, due to heat treatment utilized in the Total Regeneration method. In the multiple aliquot protocol, a fraction of the quartz grains was used to get the natural luminescence signal (TL and OSL), and in the other fractions various doses of laboratory radiation were given $(0.5,1.0,1.5,2.0,2.5 \mathrm{~Gy})$, prior to measurement of all fractions, including those used for natural radiation measurement are usually subjected to preheating at $260^{\circ} \mathrm{C}$ by $10 \mathrm{~s}$ in order to eliminate the unstable signal, and the luminescent signal was normalized with the mass. Then, TL or OSL measurements were performed and growth curves were plotted. Each point in the growth curve is the mean value of 6-10 aliquots, and the error bar means the standard deviation of these values. The $Q$ value is read off as the intercession on the dose axis in the OSL case, and for TL the interception was made with the line that is related to residual TL intensity $\left(\mathrm{TL}_{\text {res }}\right)$. The TL signal did not deplete totally when the crystal was exposed to sunlight; a short intensity always remained $\left(\mathrm{TL}_{\text {res }}\right)$, which should be subtracted from the natural signal.

For the TL dating, the effective TL intensity of the $350{ }^{\circ} \mathrm{C}$ peak of quartz was used for evaluating the accumulated doses, whilst for the OSL dating the maximum intensity of the decay curve was considered. All the samples were dated by both TL and OSL methods.

Ages were obtained through the following equation: $\mathrm{A}=\mathrm{Q}(\mathrm{Gy}) / \mathrm{AD}(\mathrm{Gy} / \mathrm{yr})$, where $\mathrm{Q}$ is the equivalent dose, which is the dose that the crystal 
has received since his burial or heating, and $\mathrm{AD}$ is the annual dose rate of the sampling place it is calculated by radioisotopes concentrations and determined by gamma-spectroscopy. Values of $\mathrm{Q}$ are obtained through Multiple aliquots additive doses (Aitken 1985, Wintle 1997).

\section{RESULTS}

Samples of mud wall, sediments and brick were analyzed, and the samples names and respective features are shown in Table I. The results obtained by Instrumental Neutron Activation Analysis (INAA) are listed in Table II. The elements with higher concentrations were: $\mathrm{Na}(0.22-1.15 \mathrm{mg} / \mathrm{g})$, Fe (14.7-32.3 mg/g), La (46.4-77.4 ppm), Th (27.9-34.4 ppm), U (5.6-6.3 ppm), Cr (47.8-76.8 ppm), Ce (89.2-127.2 ppm) and Hf (13.3-28.7 $\mathrm{ppm})$. The radioactive isotopes contents are higher than those found in ordinal soils, and they have high concentrations of $\mathrm{Ce}$ and Th like monazite sands (Mohanty et al. 2003). These results are in agreement with those determined by gammaspectroscopy, taking into account the respective uncertainties. These results are shown in Table III.

TL glow curves of MTR6 quartz with natural dose and natural with 5 and 10 Gy of additional doses are shown in Figure 2a The TL glow curve is composed by two overlapped peaks at 325 and $375^{\circ} \mathrm{C}$ and resulted in an apparent peak at $350^{\circ} \mathrm{C}$. The Plateau test was performed and a good plateau, between 330 to 375 oC interval, was obtained. Figures $3 \mathrm{a}$ and $3 \mathrm{~b}$ show TL and OSL growth curves obtained for the MTR6 mud wall sample, which is an unheated sample. Therefore, the $\mathrm{TL}_{\text {res }}$ intensity should be subtracted. All the samples were dated both by TL and OSL and the results were similar. The results of equivalent doses $(\mathrm{Q})$, annual dose rates, TL and OSL ages are listed in Table II, as well as, C-14 ages of the bones of mummified nuns.

TABLE II

Concentrations of elements determined by instrumental neutron activation analysis (inaa), found in sediments and brick collected from mummified nuns grave, located at art sacra museum, state of São Paulo, Brazil.

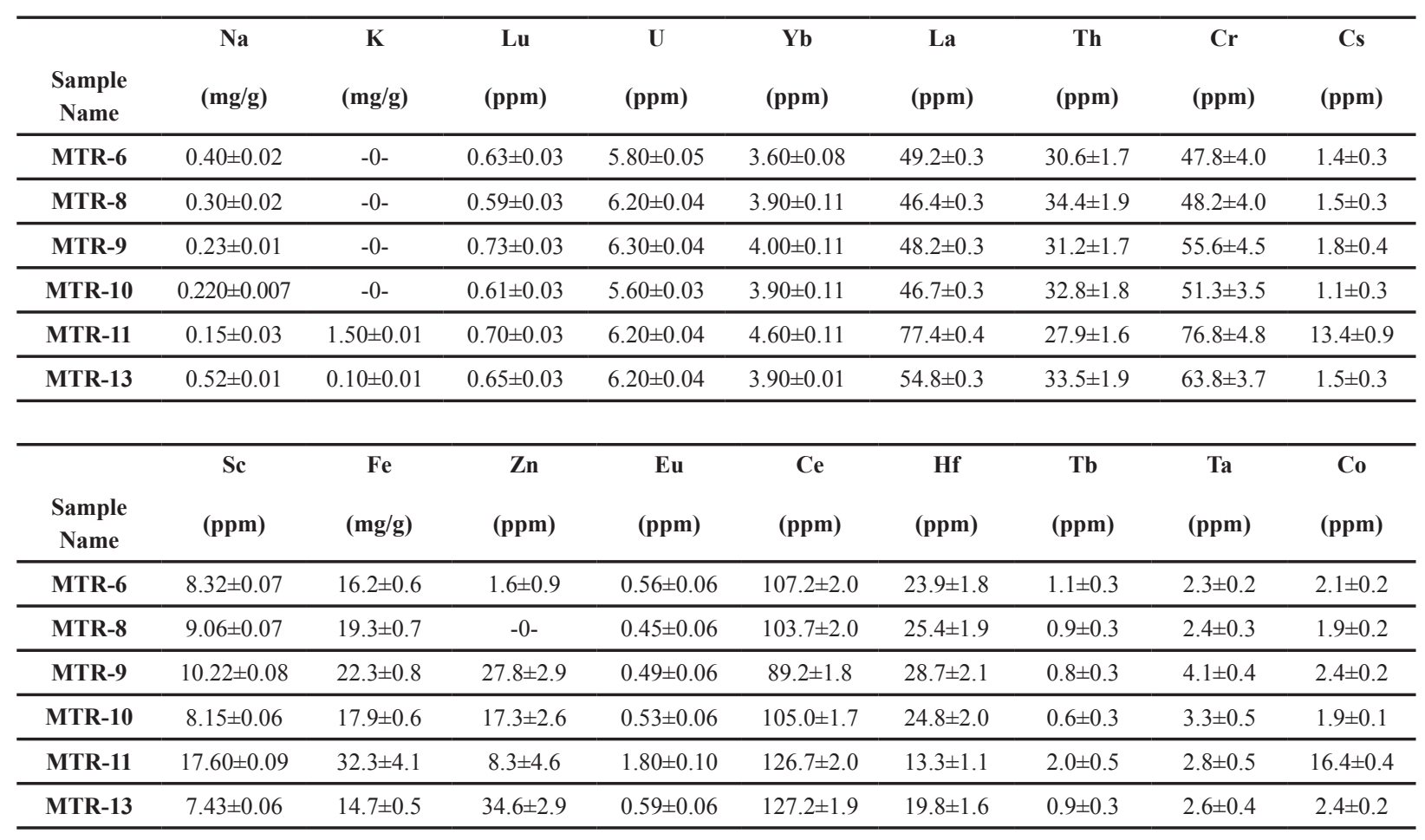


TABLE III

Natural radioisotopes contents found by gamma spectroscopy, annual dose rates (DA), equivalents doses (Q), ages by TL and OSL (before the present-day), and ages by conventional Radiocarbon method (before 1950=BP).

\begin{tabular}{|c|c|c|c|c|c|c|c|c|c|}
\hline $\begin{array}{c}\text { Sample } \\
\text { Name }\end{array}$ & U (ppm) & Th (ppm) & K (\%) & $\begin{array}{c}\text { DA } \\
(G y / k \\
\text { year })\end{array}$ & $\begin{array}{c}\text { Q } \\
(\mathrm{Gy})\end{array}$ & $\begin{array}{c}\text { P } \\
(G y)\end{array}$ & $\begin{array}{c}\text { Age TL } \\
\text { (years) }\end{array}$ & $\begin{array}{c}\text { Age } \\
\text { OSL } \\
\text { (years) }\end{array}$ & $\begin{array}{c}\text { Age } \\
\text { C-14 } \\
\text { (years) }\end{array}$ \\
\hline MTR 6 & $6.6 \pm 0.4$ & $27.9 \pm 1.4$ & $1.18 \pm 0.03$ & $4.0 \pm 0.2$ & $0.67 \pm 0.07$ & $0.65 \pm 0.05$ & $168 \pm 25$ & $163 \pm 20$ & $(70 \pm 40)$ BP or 131 \\
\hline MTR 8 & $7.9 \pm 0.3$ & $34.0 \pm 1.7$ & $3.82 \pm 0.11$ & $4.8 \pm 0.2$ & $1.12 \pm 0.12$ & $1.01 \pm 0.03$ & $233 \pm 35$ & $210 \pm 15$ & $(170 \pm 40) \mathrm{BP}$ or 231 \\
\hline MTR 9 & $5.0 \pm 0.2$ & $20.3 \pm 1.0$ & $0.88 \pm 0.03$ & $3.0 \pm 0.3$ & $1.49 \pm 0.06$ & $1.26 \pm 0.06$ & $497 \pm 70$ & $420 \pm 20$ & \\
\hline MTR 10 & $6.5 \pm 0.7$ & $31.6 \pm 1.6$ & $1.40 \pm 0.04$ & $4.2 \pm 0.3$ & $0.99 \pm 0.05$ & $0.94 \pm 0.03$ & $236 \pm 28$ & $224 \pm 10$ & \\
\hline MTR11 & $8.5 \pm 0.9$ & $30.2 \pm 1.5$ & $2.61 \pm 0.08$ & $4.6 \pm 0.3$ & $1.03 \pm 0.05$ & $0.94 \pm 0.02$ & $224 \pm 25$ & $204 \pm 10$ & \\
\hline MTR 13 & $9.56 \pm 0.08$ & $34.9 \pm 1.7$ & $1.30 \pm 0.04$ & $5.3 \pm 0.2$ & $2.07 \pm 0.24$ & $1.86 \pm 0.04$ & $390 \pm 60$ & $351 \pm 20$ & \\
\hline
\end{tabular}
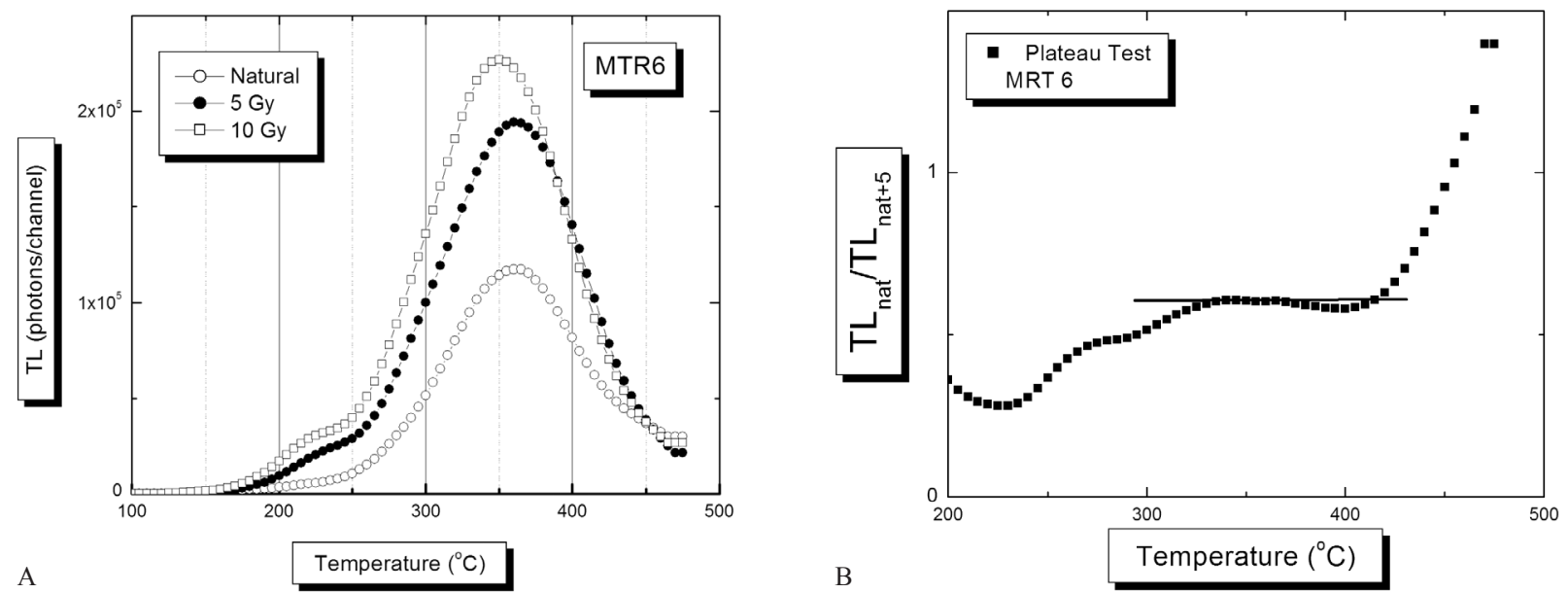

Fig.2: a) TL glow curves of MTR6 samples before and after gamma-ray irradiation of 5 and 10 Gy, b) Plateau Test, ratio of the TL intensity of MTR6 sample before gamma-ray irradiation to that after gamma irradiation of $5 \mathrm{~Gy}$.

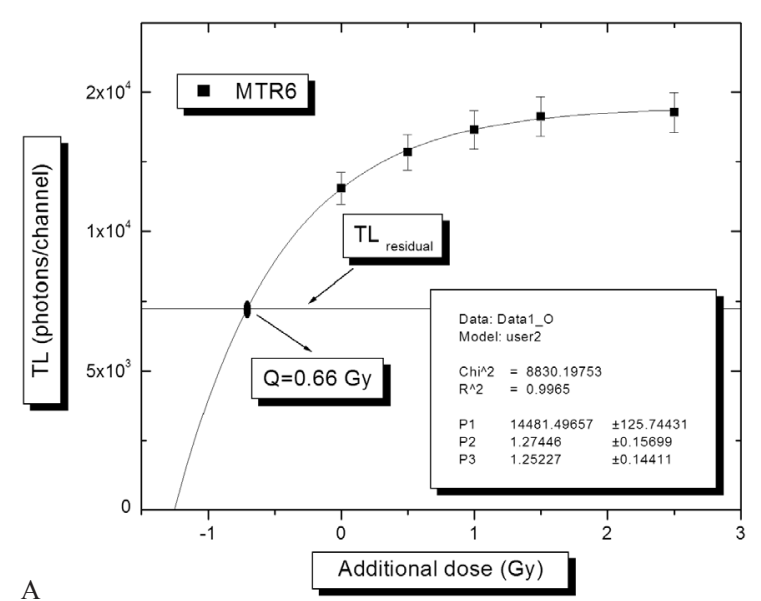

Fig.3: Growth curves of TL and OSL signals for MTR6 samples, shown in a) and b), respectively, as a function of additive dose. The equivalent doses $\mathrm{Q}$ are obtained from the figures.

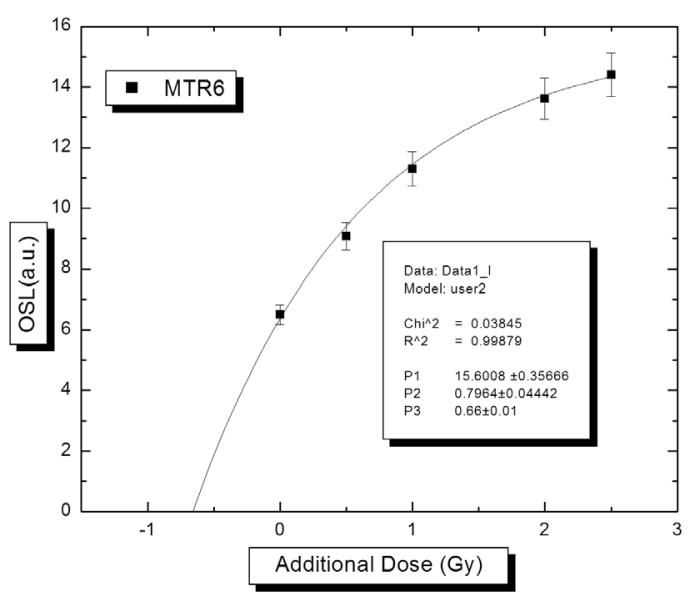

B 


\section{DISCUSSION}

TL glow curves provided by quartz from sediments and bricks exhibited two peaks, at $220^{\circ} \mathrm{C}$ and $350^{\circ} \mathrm{C}$, which were used for dating. A high residual TL was observed. The ages (MTR8, MTR10 and MTR11) related to the eighteenth century are in agreement with the radiocarbon age of 231 years, which resulted in the year 1780 (2011-231). The other radiocarbon age of 131 years is related to the year 1880 and can be associated to the sample MTR6, which supplied OSL age about 163 years $(2011-163=1848)$ and 168 years $(2011-168=1843)$ with TL measurements. The results obtained with MTR9 and MTR13 are too old; in these cases the natural luminescence signals were probably not depleted completely.

The concentrations of natural radioactive isotopes in the samples were higher than usually found in sediments; one reason for this high value could be the organic material, such as remains of plants, which were mixed with the sediment. These high radioisotope concentrations may be the cause of the nuns mummification. When the organic material is exposed to a controlled dose of ionizing radiation such as beta or an electromagnetic radiation such as gamma rays or X-rays, the dehydration of the material can occur. This treatment may inhibit the reproduction of microorganisms that cause material putrefaction and also stop the biological processes that take place in plant or animal tissue that comprises the material.

It can be concluded that they were buried in two different times, being the mummy of the bottom older than the one located in front of the grave.

\section{RESUMO}

Este artigo apresenta os resultados de datação por TL e OSL de solos, e fragmentos de tijolos de um túmulo, que foi ocupado por duas freiras mumificadas encontradas no Mosteiro da "Luz", localizado no Estado de São Paulo, Brasil. As idades encontradas por TL e OSL foram comparadas às obtidas a partir de C-14 dos colágenos contidos em amostras de osso das múmias. A maioria das idades obtidas são do século XVIII. A espectroscopia de radiação-gama foi utilizada para avaliar concentrações de radioisótopos naturais nas amostras e para calcular as taxas de dose anual que resultaram em 3,0 a 5,3 Gy/kano. As concentrações radioativas são próximas daquelas obtidas através de Análise por Ativação de Nêutrons. Os conteúdos de elementos $\mathrm{U}$, Th e Ce são superiores aos encontrados na maioria dos sedimentos.

Palavras-chave: datação, Termoluminescência (TL), Luminescência Opticamente estimulada (LOE), Freiras Mumificadas, Mosteiro da "Luz".

\section{REFERENCES}

AITKEN MJ. 1985. Thermoluminescence Dating, London: Academic Press, London, England, p. 221-237.

BANERJEe D, BøtTer-JENSEN L AND MurRAY AS. 1999. Retrospective dosimetry: preliminary use of the single aliquot regeneration (SAR) protocol for the measurement of quartz dose in young house bricks. Radiat Prot Dosim 84(1-4): 421-426.

DANIEL SF, BOYd CA AND SAUNDERS DF. 1953. TL as a research toll. Science 117: 343-349.

GÖKSU AHY, SCHWENK P AND SEMIOChKINA N. 2001. Investigation of the thermal stability of $210^{\circ} \mathrm{C}$ TL peak of quartz and dating the components of terrazzo from the monastery church of Tegernsee. Radiat Meas 33(5): 785-792.

Gozzi G, Tatumi SH, Kassab LRP, Munita CS, Paiva RP AND MOMOSE EF. 2001. Study of thermoluminescence and optical stimulated luminescence properties of quartz crystal. Radiat eff defects S 154: 347-353.

Grogler N, Houtermans FG AND Stauffer H. 1960. Ueber die Datierung von keramik und ziegel durch thermolumineszenz. Helv Phys Acta 33: 595-596.

KenNEDY G AND KNOPFF L. 1960. Dating by thermoluminesence. Archæology 13: 147-148.

Martins G, Kashimoto EM AND TATUMI SH. 1999. Datações arqueológicas em Mato Grosso do Sul. Rev Mus Arqueol Etnol 9: 73-93.

MAZESS RB AND ZIMMERMAN DW. 1966. Pottery dating from thermoluminescence. Science 152: 347-348.

MEDLIN WL. 1959.Thermoluminescence properties of calcite. J Chem Phys 30: 451-458.

MEDLIN WL. 1964 Trapping centers in thermoluminescence calcite. Phys Rev 135: 1771-1779.

MEJDAHL V. 1969. Thermoluminescence dating ancient Danish ceramics. Archaeometry 11: 99-104. 
MEJdAHL V AND BøTteR-JENSEN L. 1994. Luminescence dating of archaeological materials using a new technique based on single aliquot measurements. Quaternary Sci Rev 13(5-7): 551-554.

MEJDAHL V AND BøTteR-Jensen L. 1997. Experience with the SARA OSL method. Radiat Meas 27( 2): 291-294.

Miyamoto M And WatanaBe S. 1975. Datação de peças arqueológicas pelo método da TL. An Acad Bras Cienc 47: 197-213.

MOHANTY AK, DAS SK, ViJayan V, SENGUPTA D AND SAHA SK. 2003. Geochemical studies of monazite sands of Chhatrapur beach placer deposit of Orissa, India by PIXE and EDXRF method. Nucl Instrum Meth B 211(1): $145-154$.

ÖKE G AND YURDATAPAN E. 2000. Optically stimulated luminescence dating of pottery from Turkey. Talanta 53(1): 115-119.
RALPH EK AND HAN MC. 1966. Dating of pottery by thermoluminescence. Nature 210: 245-247.

SPOONER NA, AitKen MJ, SMITH BW, Franks M AND MCELROY C. 1990. Archaeological dating by infraredstimulated luminescence using a diode array. Radiat Prot Dosim 34: 83-86.

SZMUK PE AND WATANABE S. 1971. Dating of brazilian indian pottery by TLD. Publ IEA 231.

TATUMI SH, Martin GR, Kashimoto EM, AYTA WEF AND WATANABE S. 1998. Thermoluminescence dating of archaeological ceramics collected from State of Mato Grosso do Sul, Brazil. Radiat Eff Defect S 146: 297-302.

WINTLE A. 1997. Luminescence dating: laboratory procedures and protocols. Radiat Meas 27(5/6): 769-817. 